\title{
DETERMINATION OF GROUNDWATER AND OVERLAND FLOW DIRECTION IN NDELE, RIVERS STATE, NIGERIA
}

\author{
Kekwaru, M.M, Nwankwoala, H.O \\ Department of Geology, University of Port Harcourt, P.M.B 5323 Port Harcourt. \\ *Corresponding Author Email: nwankwoala_ho@yahoo.com
}

This is an open access article distributed under the Creative Commons Attribution License, which permits unrestricted use, distribution, and reproduction in any medium, provided the original work is properly cited.

\section{ARTICLE DETAILS}

\section{Article History:}

Received 26 June 2018 Accepted 2 July 2018 Available online 1 August 2018

\section{ABSTRACT}

This study was carried out to determine the direction of flow of groundwater and overland flow at Ndele, Emuoha local Government area of Rivers state, Nigeria. The Global Positioning System (GPS) was used to determine the longitude, latitude and the elevation above mean sea level at ten (10) locations spread across the study area. Water level meter was also used to measure the depths to water table which was used to calculate the hydraulic head in each of the ten (10) hand dug wells analyzed. Surface elevation and hydraulic head contour maps were then generated using surfer 8 computer software. The surface elevation and hydraulic head contour maps developed revealed that the overland flow and groundwater flow are towards the same direction; South to South-Western parts of the region. This makes the watershed area more vulnerable compared to other locations in the study area. More efforts should be made towards establishing eco-friendly practices in the North, North-Western and North-Eastern parts of the community to minimize groundwater contamination. It is recommended that boreholes be sited in the North, North-Western and North-Eastern parts of the community to avoid contamination of potable water sources. Moreso, an appropriate geophysical survey must be carried out before any borehole is drilled in the area.

\section{KEYWORDS}

Overland flow, hydraulic head, watershed, groundwater contamination, Ndele.

\section{INTRODUCTION}

Water is a resource vital to all life on earth [1]. It is a natural resource that occur either as fresh water or saline water and the quality can be altered by anthropogenic activities. Groundwater is the water that lies beneath the earth surface, filling the pore spaces of saturated zones of sedimentary rocks and in the basement terrain, it is found in fractures and fault zones [2].

Groundwater does not usually remain stationary but moves or flows underground according to forces acting on the groundwater [3]. Ground water moves along a flow path perpendicular to equipotential lines and the direction of movement is from lines of higher value to lines of lower value (i.e., higher to lower elevation or pressure). Groundwater flow paths are usually shown by arrows on equipotential surface plots pointing in the direction of groundwater flow. Groundwater usually flows towards and eventually drains into streams, lakes, rivers, seas, ponds and boreholes. The flow of groundwater in aquifer does not always reflect the flow of water on the surface $[4,5]$. It is necessary to know the direction of groundwater flow to determine the recharge zones and make sure that human activities in the area do not pose threat to the quality of the groundwater to enable a sustainable use of the resources. Given that water always flows from a region of higher head to a region of lower head, it is found that groundwater use within an area at a higher water level directly affects the quality of water available to people living in regions of lower water levels [6].

The rate of overland flow in an area can be determined by the slope of the area and this plays a major role in the recharge of groundwater in that area. The recharge system of groundwater has been identified as the major source of its contamination [7]. Groundwater contamination in an area could also be attributed to the direction of flow of groundwater in the area. Areas with poor waste management plan such as indiscriminate waste dump sites, open pit toilets, effluents from industries, oil spill sites etc are susceptible to groundwater contamination. Leachates are formed that migrate with groundwater flow, thereby contaminate groundwater in the direction of its flow.

Furthermore, it is necessary to estimate the direction of flow of groundwater in an area and take steps to ensure anthropogenic activities at the recharge area do not contaminate the water quality abstracted from shallow aquifers in the vicinity [8]. Also, the direction of overland flow in an area does not always depict the groundwater flow direction in the area hence, the need to employ field methods to determine the variation in hydraulic heads of different locations in the study area and estimate groundwater flow direction.

\subsection{Study Location}

Ndele is a town located in emohua L.G.A of Rivers state. Ndele is located approximately between latitude $04^{\circ} 58^{\prime} 05^{\prime \prime}-04^{\circ} 58^{\prime} 08^{\prime \prime} \mathrm{N}$ and longitude $006^{0} 44^{\prime} 44^{\prime \prime}-006^{\circ} 45^{\prime} 05^{\prime \prime} \mathrm{E}$ (figure 1) in the South South region of Nigeria. Ndele is bounded to the north by Elele alimini and Omagwa and then to the south by Rumuekpe.

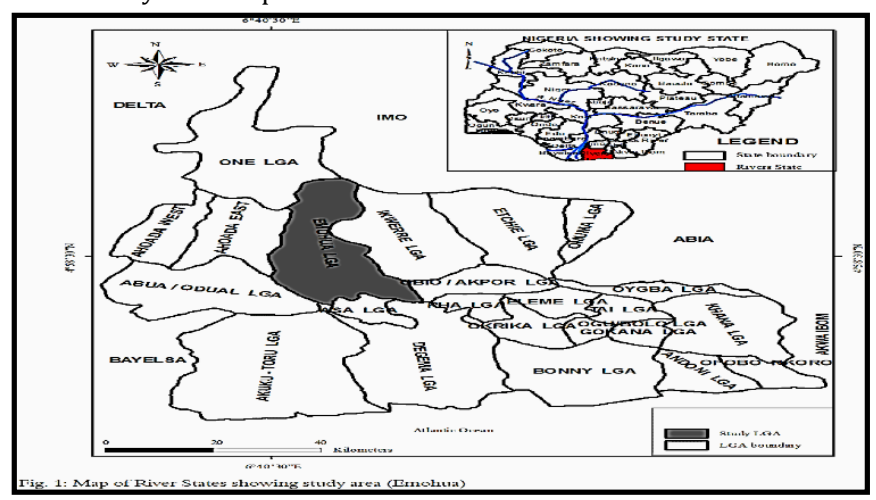

Figure 1: Map of Rivers State Showing the Local Government Area of Study 


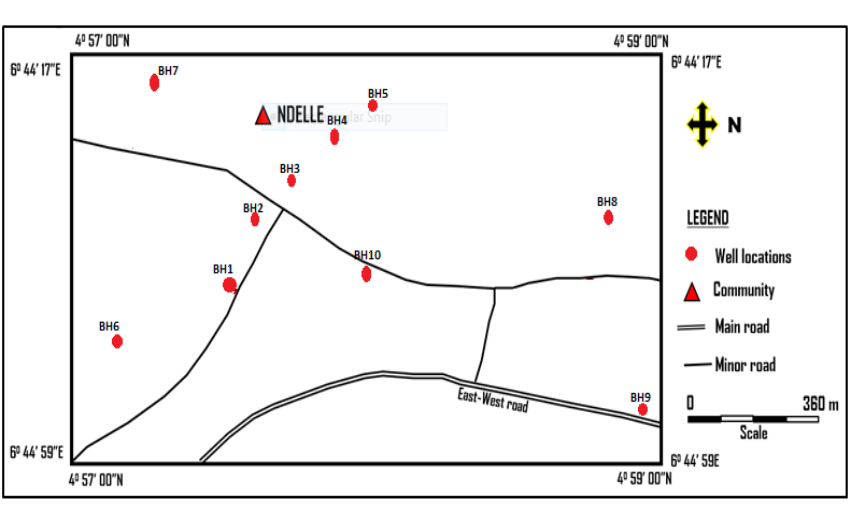

Figure 2: The Base Map of Ndele Community showing well locations

\subsection{Relief and Drainage}

The study area lies within the coastal flat plains of the Niger Delta which is a depositional environment basically and of almost featureless land sloping gently above mean sea level at the coastal fringe, though relatively low elevation occurs around the shore lines, waterfronts and stream [9]. The area is affected by tide with a maximum range of tide fluctuating between $1.8 \mathrm{~m}$ below mean sea level and $2.2 \mathrm{~m}$ above mean sea level [10]. The study area which is in Rivers State is drained by numerous rivers and creeks sourced from River Niger. The study area, Ndele is drained by the new Calabar River [10].

\subsection{Climate and Vegetation}

The study area lies within the Niger Delta which features tropical monsoon with two distinct seasons; the rainy season which is usually lengthy and heavy and the dry season which is normally very short. Only the months of December and January truly qualifiers the dry season months. In Port-
Harcourt, there is a well-defined pattern of the monthly rainfall, described as bimodal. The harmattan which climatically influences many cities in West Africa is less pronounced in the study area. Temperatures throughout the year in the city are relatively constant, showing little variation throughout the course of the year [11]. Average temperature is between $25^{\circ} \mathrm{C}$ to $28^{\circ} \mathrm{C}$ in Port Harcourt city, which is the closest urbanized district to the study area. High rainfall is attributed to the proximity to the sea and its location on the parts of rain bearing winds.

The vegetation of a place is usually as a result of the climatic conditions that characterizes the area. The study area is characterized by two types of vegetation; the rain forest and the swamp forest vegetation which are mainly the vegetation that generally characterize the Niger Delta. The study area is mainly characterize by swampy forests which contains water logged grasses and shrubs and also there are presence of palm trees, plantain trees and other types of mangrove trees.

\subsection{Brief Geology}

The study area, Ndele in Emuoha Local Government Area of Rivers state is located within the Niger Delta region of Nigeria, situated in the gulf of Guinea and therefore has same geology of the Niger Delta. The Niger Delta is composed of marine shale at the base of its stratification, an overlying formation of intercalation of sandstone and clays of marginally marine origin, but eventually grading upward into a huge sandstone deposit. The groundwater formation is a multi-aquifer system because of the presence of certain clayey strata in formations of various thicknesses that acts as confining layer between two rock strata. The present day Niger Delta was formed during the tertiary period as a result of the interplay between subsidence and deposition arising from a succession of transgression and regression of the three main tertiary subsurface litho-stratigraphic units of Akata, Agbada, and Benin Formations [12]. Further studies and evidence from deep wells in the Niger Delta has also proven that the Niger Delta has a three litho-stratigraphic depositional succession (Akata, Agbada and Benin Formations) with an approximate thickness of over $5000 \mathrm{~m}$ of sediment body.

Table 1: Stratigraphic Sequence of the Tertiary Niger Delta [12]

\begin{tabular}{|c|c|c|c|c|}
\hline AGE & \multicolumn{2}{|c|}{ SURFACE FORMATION } & SUBSURFACE & ENVIRONMENT \\
\hline \multirow{4}{*}{$\begin{array}{l}\text { Pliocene to Recent } \\
\text { Miocene to Recent } \\
\text { Eocene to Recent } \\
\text { Paleocene }\end{array}$} & \multicolumn{2}{|l|}{ Coastal Plain Sands } & \multirow[t]{2}{*}{ Benin Formation } & \multirow[t]{2}{*}{ Continental } \\
\hline & $\begin{array}{l}\text { OgwashiAsaba } \\
\text { formation }\end{array}$ & Ijebu Formation & & \\
\hline & Ameki Formation & $\begin{array}{l}\text { Ilaro } \quad \text { Formation } \\
\text { Oshobu Formation }\end{array}$ & Agabada Formation & Paralic \\
\hline & \multicolumn{2}{|l|}{ Imo Formation } & Akata Formation & Marine \\
\hline
\end{tabular}

\section{METHODS OF STUDY}

\subsection{Determination of Direction of Overland Flow}

The direction of overland flow was determined by estimating the slope and its direction in the study area. This was done by the use of Global Positioning System (GPS) etrex-30 to determine the surface elevations of different points in the study area with respect to Mean Sea Level (msl). A contour map showing the variation of surface elevations in the study area was then produced indicating the direction at which the surface runoffs flow; from a region of higher elevation to a region of lower elevation.

\subsection{Determination of Groundwater Flow Direction}

A total of ten (10) hand dug wells were used to estimate the hydraulic heads at different locations in the study area. With the aid of water level meter, the depth to water table was measured and recorded. The Global Positioning System (GPS) was used in determining the latitudes and longitudes of the wells and the surface elevation with respect to Mean Sea Level on the surface of the earth. The surface elevation at different point varied. This uniform water level coincided with static water level in the case of an unconfined aquifer while it was the piezometric surface in the aquifer was confined [13]. The values of the static water levels were contoured on the map of Ndele with lines that represent the water table contours. According to a study, ground water flows from the highest values of hydraulic head to the lowest values in a direction perpendicular to the hydraulic head contour lines [13]. 


\section{RESULTS AND DISCUSSION}

Table 2: Field records obtained from hand-dug wells in Ndele

\begin{tabular}{|c|c|c|c|c|c|c|c|}
\hline Wells & GPS Location & $\begin{array}{l}\text { Latitude } \\
\text { (N) }\end{array}$ & $\begin{array}{l}\text { Longitude } \\
\text { (E) }\end{array}$ & $\begin{array}{ll}\text { Surface } & \text { Elevation } \\
S_{\mathrm{E}}(\mathrm{m}) & \end{array}$ & $\begin{array}{l}\text { Water Depth } \\
D_{\mathrm{w}}(\mathrm{m})\end{array}$ & $\begin{array}{l}\text { Hydraulic head } \\
\mathrm{H}_{\mathrm{H}}(\mathrm{m})\end{array}$ & $\begin{array}{l}\text { Well Diameter } \\
\text { (m) }\end{array}$ \\
\hline 1 & & $04^{\circ} 58^{\mathrm{I}} 219^{I I I}$ & $006^{0} 44^{\prime} 699^{I I I}$ & 21 & 1.26 & 19.7 & 1.11 \\
\hline 2 & & $04^{0} 58^{\mathrm{I}} 058^{\mathrm{II}}$ & $006^{0} 44^{\prime} 494^{I I}$ & 21 & 2.54 & 18.5 & 1.00 \\
\hline 3 & & $04^{0} 58^{\mathrm{I}} 065^{\mathrm{II}}$ & $006^{0} 44^{\prime} 437^{I I I}$ & 23 & 2.28 & 20.7 & 1.11 \\
\hline 4 & & $04^{0} 58^{\mathrm{I}} 024^{\mathrm{II}}$ & $006^{0} 44^{1} 495^{I I}$ & 21 & 2.34 & 18.7 & 0.87 \\
\hline 5 & & $04^{0} 58^{\mathrm{I}} 038^{\mathrm{II}}$ & $006^{\circ} 44^{\prime} 434^{I I I}$ & 31 & 3.09 & 27.9 & 0.96 \\
\hline 6 & & $04^{0} 58^{\mathrm{I}} 093^{\mathrm{II}}$ & $006^{\circ} 44^{\mathrm{I}} 446^{I I}$ & 33 & 3.26 & 29.7 & 0.80 \\
\hline 7 & & $04^{0} 58^{\mathrm{I}} 114^{\mathrm{II}}$ & $006^{\circ} 44^{\prime} 390^{I I}$ & 31 & 3.82 & 27.2 & 0.92 \\
\hline 8 & & $04^{0} 58^{1} 719^{I I}$ & $006^{0} 44^{1} 751^{I I}$ & 30 & 2.73 & 27.3 & 0.86 \\
\hline 9 & & $04^{0} 58^{\mathrm{I}} 791^{\mathrm{II}}$ & $006^{0} 44^{1} 657^{I I I}$ & 32 & 2.88 & 29.1 & 0.84 \\
\hline 10 & & $04^{0} 58^{\mathrm{I}} 853^{\mathrm{II}}$ & $006^{0} 44^{1}$ 727II & 32 & 2.70 & 29.3 & 0.95 \\
\hline
\end{tabular}

\subsection{Direction of Overland Flow}

The 2-D elevation contour map of the study area and 3-D elevation contour map of the study area (Figures $3 \& 4$ ) explains that the direction of flow of surface runoffs in the study area are towards one direction, the South. This is simply attributed to the uneven elevation encountered at different points in the study area which results to a downward sloping towards the watershed area. The watershed locations is situated down South of the full study area and this implies that the surface runoffs flows to the watershed locations of the study area. This makes the watershed locations highly susceptible to flow due to surface runoffs.

Furthermore, it is also observed that almost all surface runoffs in the study area are directed towards the watershed area which has the drainage system that drains water to a fresh water swampy forest in the area. Due to the failure of the drainage system in the watershed area, all surface runoffs that flow towards this area stagnates on the street and in the compounds of residents of the watershed area, this poses great threat to the environment and health of the residents of this area.

\subsection{Groundwater Flow Direction}

The values of the hydraulic head and static water level obtained from each well location were contoured carefully on a map by joining equal values of the hydraulic heads and making sure none of the lines overlapped or cut across each other. This was improved upon with the aid of surfer 8 computer software. The water table elevation values which also represent the hydraulic head values of the various wells are in meters and are also placed beside the contour map decreasing downwards from higher heads to lower heads (Figure 5).

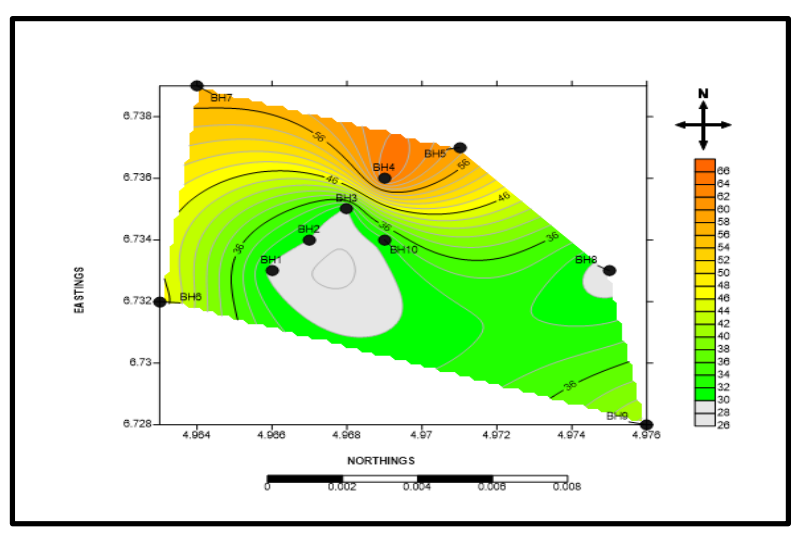

Figure 3: 2D elevation contour map showing the direction of overland flow

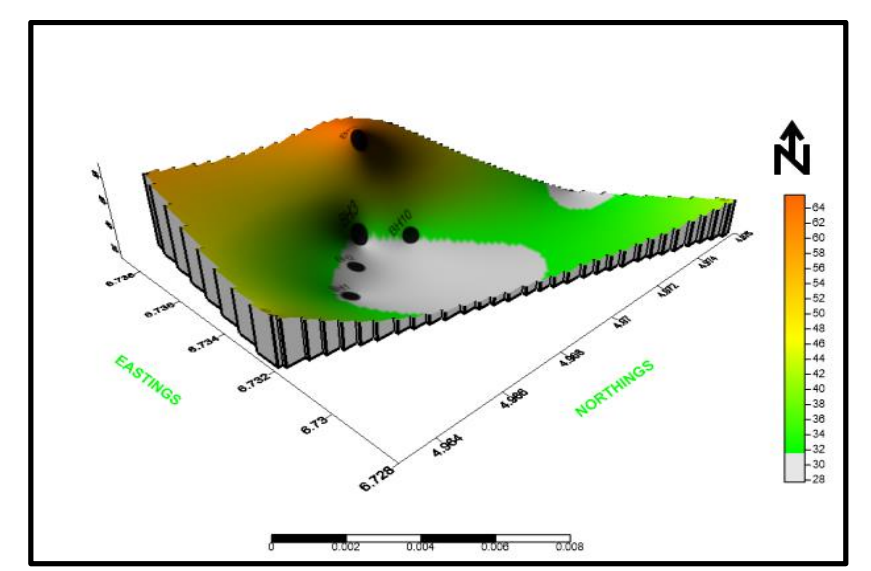

Figure 4: 3D elevation contour map showing the direction of overland flow

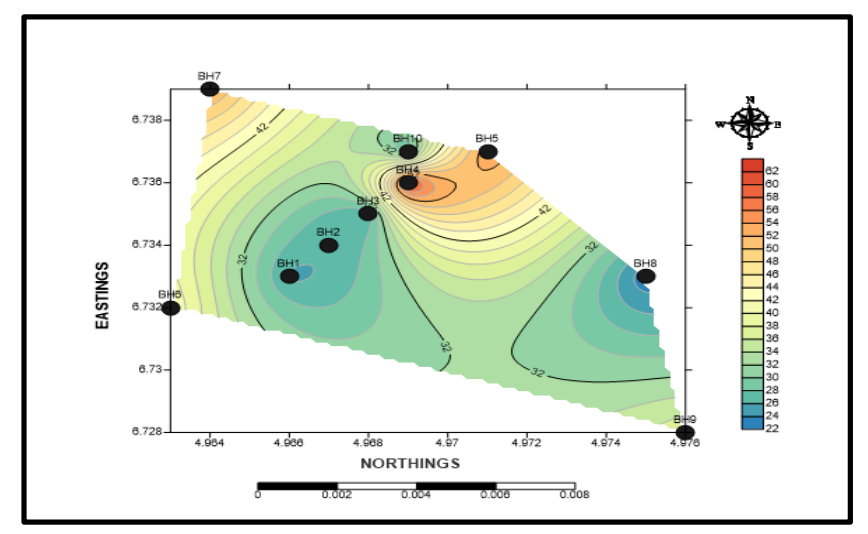

Figure 5: 2D Hydraulic Head Contour map showing the groundwater flow direction

\section{CONCLUSION}

The results obtained from the 2D and 3D elevation contour map of Ndele, indicates that groundwater flows from the North, North-eastern part of the community down to the South and South-western part of the community. This means that occupants in the North, North-western and North-eastern parts of the community should take eco-friendly measures seriously so that their activities does not contaminate groundwater and 
therefore not endangering the lives of those occupying the South to Southwestern parts of the community.

Based on the aquifer system and groundwater flow direction in Ndele community, it is recommended that dumpsites should be sited within the South to South-western parts of the region and not in the North, Northeast and North-western parts of the region to minimize groundwater contamination by leachates from dumpsites. Drilling of boreholes for potable water supply in the area should be sited within the North, Northeast and North-western parts of the region, at least $10 \mathrm{~m}$ away from an open pit toilets to avoid pollution of drinking water sources.

\section{REFERENCES}

[1] World Health Organization (WHO) .2003. Guideline for Drinking Water Quality Geneva, (WHO/SDE/WSH 03.04).

[2] Fetter, C.W. 2001. Applied Hydrogeology 4th Ed, Prentice Hall, New Jersey. 598.

[3] Todd, D.L. 1980. Groundwater Hydrology, John Wiley and Sons, New York, pp. 267 - 315.

[4] Delleur, J.W. 1999. Elementary Groundwater Flow and Transport Processes, In Handbook of Groundwater Engineering, Edited by J. W. Delleur, pp. 41.

[5] Oborie, E., Nwankwoala, H.O. 2017. Determination of groundwater flow direction in Yenagoa, Bayelsa State, Nigeria. Journal of Scientific Achievements, 2 (9), 23 - 27.

[6] Wehrmann, H.A. 2007. Groundwater Occurrence and Movement: An
Introductory Discussion with Application to North-eastern Illinois, Centre for Groundwater Science Illinois State Water Survey, pp. 12- 45.

[7] Nwankwoala, H.O., Udom, G.J. 2011. Hydrogeochemical evaluation of Groundwater in parts of eastern Niger Delta. Journal of Academic and Applied Studies, 1 (2), 33-58.

[8] Freeze, R.A., Cherry, J.A. 1979. Groundwater, Prentice-Hall, Englewood cliffs New Jersey, 604-614

[9] Etu-Efeotor, J.0. 1997. Fundamentals of Petroleum Geology. Paragraphics Ltd., pp 114-116.

[10] Iloeje, P. 1972. A preliminary sub-soil investigation. International Journal of Environmental Science Management and Engineering Research, $1(2), 459-522$.

[11] Offodile, M.E. 2002. Groundwater Study and Development in Nigeria. Mecon Eng. Services Ltd, Jos, Nigeria. pp239 -255.

[12] Short, K.C., Stauble, A.J. 1967. Outline of geology of Niger Delta. AAPG Bull., 51, 761-779.

[13] Buddemeier, R.W., Schloss, J. A. 2000. Groundwater Storage and Flow. www.kgs.ku.edu. 